\title{
PERAN PENDIDIKAN DAYAH \\ DALAM PEMBENTUKAN KARAKTER PEMUDA ACEH (STUDI KASUS DI ACEH TENGGARA)
}

\author{
M. Arif Idris \\ Sekolah Tinggi Agama Islam Negeri Teungku Dirundeng Meulaboh \\ Email: arif.idris.ibrahim@gmail.com
}

\begin{abstract}
Abstrak
Di Aceh peran dayah sangat penting mengingat keberadaannya didukung oleh masyarakat terutama dalam pendidikan. Permasalahan lainnya muncul jika dilihat dari konteks sosial budaya masyarakat ketika dihadapi dengan kemajemukan yang hadir ditengah masyarakat khususnya di daerah perbatasan Aceh. Keberadaan Dayah di tengah-tengah kemajemukan masyarakat yang terdiri dari berbagai macam suku dan agama tentunya menjadi tantangan tersendiri bagi keberadaan Dayah sebagai lembaga yang membetuk karakter pemuda Aceh. kondisi seperti inilah yang terjadi di Aceh Tenggara. Tulisan ini bertujuan melihat bagaimana peran pendidikan dayah dalam membentuk karakter pemuda di Aceh Tenggara. Penelitian ini menggunakan pendekatan kualitatif dengan subjek adalah pimpinan dayah, dewan guru dan para santri yang ada di dayah. Dayah tersebut dipilih secara random. Adapun teknik pengumpulan data menggunakan teknik observasi, wawancara dan dokumentasi. Kemudian data-data tersebut dianalisis dengan menggunakan langkah-langkah reduksi data, display. Hasil dari penelitian menunjukkan bahwa Dayah di Aceh Tenggara memiliki kedudukan yang penting ditengah-tengah masyarakat. Keberadaannya didukung oleh Pemerintah dan masyarakat sendiri, bahkan Aceh Tenggara salah satu kabupaten yang memiliki dayah terbanyak di Aceh. para santri lulusan dari dayah tersebut merasa adanya perbedaan sebelum menuntut ilmu di dayah dengan setelah menuntut ilmu di dayah. Dalam perkembangannya dayah tidak mengalami hambatan yang berarti.
\end{abstract}

Kata kunci: Peran Dayah, Pemuda, Pembentukan Karakter dan Aceh Tenggara.

\begin{abstract}
In Aceh, the role of Dayah is very important considering its existence is supported by society especially in education. Other problems arise when viewed from the socio-cultural context of society when faced with the diversity present in the midst of society, especially in the border area of ACEH. The existence of Dayah amid the diversity of society consisting of various tribes and religions is certainly a challenge for the existence of Dayah as an institution that provides the character of ACEH youth. This kind of condition happened in southeast Aceh. This article aims to see how the role of education in the form of youth character in Southeast
\end{abstract}


Aceh. This study used a qualitative approach with the subject is the head of Dayah, the Council of Teachers, and the students in the Dayah. The Dayah is randomly selected. Data collection techniques using observation techniques, interviews, and documentation. Then the data is analyzed by using data reduction measures, displays. The results of research show that Dayah in southeast Aceh has an important position in the midst of society. Its existence is supported by the government and community, and one of the districts that have the most Dayah in Aceh. The students graduated from the Dayah felt a difference before studying in the father after studying in the Dayah. In the development Dayah did not experience any meaningful obstacles.

Keywords: Rules of Dayah, Youth, Character Building and Southeast of Aceh

\section{A. PENDAHULUAN}

Dayah memiliki sejarah yang panjang di Aceh sebagai lembaga pendidikan Islam. lembaga Pendidikan Dayah ini telah banyak melahirkan para ulama dan cendikiawan Islam terkemuka di Bumi Serambi Mekkah ini. Sejak berdirinya Dayah di Aceh sudah banyak ulama dan cendikiawan Islam yang lahir. Banyak dari ulama dan cendikiawan tersebut yang terkenal tidak hanya di tingkat lokal tetapi juga di tingkat Internasional.

Dalam bahasa Aceh (Dayah) adalah nama sebuah lembaga yang dikenal dengan sebutan pesantren di daerah jawa atau surau atau pondok di Thailand. Dayah sendiri berasal dari kata dalam bahasa Arab "zawiyah". Secara bahasa zawiyah berarti sudut, yang diyakini oleh masyarakat Aceh pertama kali digunakan sudut mesjid Medinah ketika Nabi memberi pelajaran kepada para sahabat di awal Islam (Marzuki, 2011).

Dayah sebagai sebuah lembaga pendidikan memiliki peran yang sangat penting dalam proses pendidikan di Aceh. Dayah sudah dikenal sejak masa kusulthanahan Aceh hingga terus berkembang sampai dengan masa sekarang ini, Dayah dalam sejarah telah melahirkan ulamaulama hebat bahkan terkenal hingga ke luar wilayah Aceh dan bahkan luar negri. Eksitensi Dayah sebagaimana yang diperkirakan oleh James T. Siegal sebagaimana yg dikutip oleh Hamdiah telah dikenal semenjak kesultanan dan turut mewarnai kehidupan masyarakat secara menyeluruh dan memainkan fungsi sosial, khususnya dalam ilmu agama. (Mashuri, 2007)

Berdasarkan orientasi tersebut, Dayah dan pondok pesantren di Aceh telah memperlihatkan perannya dalam menyukseskan program-program pembangunan, terutanama dalam bidang keagamaan dan kecerdasan anak bangsa (Mashuri, 2007). Lembaga ini terkadang dijadikan sebagai sekolah agama dan terkadang pula disaat waktu-waktu tertentu dijadikan sebagai pondok spritual (Marzuki, 2011). Adapun permulaan kegiatan belajar terfokus pada pelajaran agama dan mengajarkan kitab-kitab Arab tertentu yang telah ditetapkan oleh pimpinan.

Dayah-Dayah yang terdapat di Aceh sekarang ini dapat dikatakan sebagai "bapak" dari pendidikan Islam yang dibangun berdasarkan tuntutan dan kebutuhan zaman, yaitu dilahirkan atas kesadaran kewajiban islamiyah, yang bertugas menyebarkan dan mengembangkan agama Islam atas kesadaran kewajiban Islamiyah, sekaligus kader-kader ulama dan da'i (Marzuki, 2011). Beberapa ulama-ulama besar yang lahir dari lembaga ini, Teungku Chik Ditiro, Teungku Chik Kuta Karang, Teungku Fakinah dan lain-sebagainya. Mereka inilah orang-orang sebagian besar merupakan hasil dari didikan Dayah. 
Kehadiran Dayah tidak terlepas dari pengajaran dan dakwah Islam. Kegiatan ini terus berlangsung sampai sekarang, jumlah Dayah terus bertambah seiring bertambahnya penduduk. Bertambahnya jumlah Dayah disebabkan karena rasa kertarikan untuk mempelajari agama lebih baik, dimana Dayah merupakan tempat para penerus Islam dibekali dengan ilmu pengetahuan Agama dan pengetahuan lainnya. (Marzuki, 2011)

Namun, perkembangan Dayah di Aceh bukan berarti berjalan dengan mulus, dengan bahasa lain arus moderinitas dan arus globalisasi ini turut juga menjadi tantangan tersebesar dimana banyak kalangan pemuda Aceh mulai terpengaruh dengan arus-arus tersebut, sehingga Dayah sebagai suatu lembaga pendidikan yang penting dalam pembentukan karakter mau tidak mau harus tetap menunjukkan eksistensinya agar tidak tergerus oleh perkembangan zaman. Hal ini, harus menjadi perhatian serius ditambah lagi dengan berdirinya sekolah-sekolah umum yang menwarkan sistem pendidikan terbaru yang mana sistem pendidikan tersebut belum tentu lebih baik dari pada Dayah yang telah ratusan tahun menjadi ujung tombak pendidikan di Aceh.

Sekilas tidak ada persoalan yang disignifikan bila berbicara tentang kebaradaan Dayah di Aceh dikalangan masyarakat Muslim dikarenakan keadaan lingkungan yang mendukung. Permasalahan lainnya muncul apabila dilihat dari konteks sosial budaya masyarakat ketika dihadapi dengan kemajemukan yang hadir ditengah masyarakat khususnya didaerah perbatasan Aceh. Keberadaan Dayah di tengah-tengah kemajemukan masyarakat yang terdiri dari berbagai macam suku dan agama tentunya menjadi tantangan tersendiri bagi keberadaan Dayah sebagai lembaga yang membetuk karakter pemuda Aceh. Misalnya Aceh Tenggara. Karenanya Dalam tulisan ini penulis membahas bagaimana peran dayah dalam pembentukan karakter pemuda di Aceh Tenggara.

\section{B. METODE PENELITIAN}

Pendekatan yang digunakan dalam penelitian ini menggunakan penelitian deskriptif kualitatif. Menurut Sugiyono (2007: 10), penelitian kualitatif adalah penelitian yang bermaksud untuk memahami fenomena tentang apa yang dialami oleh subjek penelitian misalnya perilaku, cara deskriptif dalam bentuk kata-kata dan bahasa, pada suatu konteks khusu yang alamiah dan dengan memanfaatkan berbagai metode alamiah. Pendekatan kualitatif ini diambil karena dalam penelitian ini objek atau sasaran dibatasi agar data-data yang diambil dapat digali sebanyak mungkin dan tidak terjadinya pelebaran objek.

Penelitian ini dilaksanakan di wilayah Aceh Tenggara. Adapun yang menjadi objek penelitian adalah Dayah-dayah yang ada di Aceh Tenggara. Adapun proses penelitian dilakukan pada tanggal 7 Agustus 2018 sampai dengan 4 September 2018.

Data-data yang penulis gunakan untuk menyusun penelitian ini bersumber dari orang kunci (key person). Posisi orang kunci dalam penelitian merupakan hal yang utama. Orang kunci yang peneliti maksudkan.

1. Pimpinan Dayah: pimpinan Dayah merupakan orang pertama yang penulis teliti. Karena pimpinan Dayah berfungsi sebagai pemberi izin penelitian/pembuka jalan dengan responden

2. Para guru Dayah: adalah pihak-pihak yang menyelenggarakan/melaksanakan kegiatan belajar dan mengajar dan yang langusng mengetahui perubahan-peribahan karakter pada 
peserta didiknya. Para guru di Dayah diharapkan dapat memberikan data secara detail, lengkap dan akurat tentang perubahan pada anak didiknya.

3. Santri: adalah orang yang dapat dijadikan sumber penelitian. Santri dapat memberikan informasi mengenai perubahan yang dialami semenjak masuk di Dayah dan mengalami proses pembelajaran didalamnya.

Pada penelitian ini, peneliti menggunakan teknik pengumpulan data dengan teknik wawancara mendalam, observasi, dan dokumentasi. Dokumentasi dan pengumpulan data pendukung dalam penelitian ini peneliti gunakan untuk melengkapi penelitian dan untuk memaksimalkan hasil penelitian.

\section{HASIL DAN PEMBAHASAN}

Dalam bahasa Aceh (Dayah) adalah nama sebuah lembaga yang dikenal dengan sebutan pesantren di daerah jawa atau surau atau pondok di Thailand. Dayah sendiri berasal dari kata dalam bahasa Arab "zawiyah". Secara bahasa zawiyah berarti sudut, yang diyakini oleh masyarakat Aceh pertama kali digunakan sudut mesjid Madinah ketika Nabi memberi pelajaran kepada para sahabat di awal Islam (Marzuki, 2011)

Dayah/Pesantren di Aceh dalam bingkai nasional merupakan salah satu pilar pendidikan Islam di Indonesia yang ekstitensinya telah diukir jauh sebelum Negara Indonesia itu sendiri lahir. Karenanya dayah seringkali dinilai sebagai sebagai institusi pendidikan Islam tradisional yang masih eksis hingga saat ini. Secara umum kehidupan di dayah dideskripsikan sebagai suatu kompleks asrama yang didiami oleh simeudagang (ureung meudagang) atau santri, yang sangat takzim berguru kepada kepada seorang pimpinan dayah yang lazimnya dipanggil teungku dengan segenap keahliannya dalam menguasai ilmu-ilmu keislaaman dan lokasinya terletak disuatu tanah yang luas. Menurut Zamaksyari Dhofir menyatakan bahwa unsur penting dari pesantren atau dayah adaalah pimpinan (teungku, Abu), orang yang sedang belajar, asrama atau pondok sebagai tempat tinggal, masjid dan pengkajian kitab kuning (Muhammad, 2010: 54-55).

Pada akhirnya sampai sekarang dayah terus berkembangan dan menjadi terus berkembang dan tersebar keseluruh pelosok Aceh. Perkembangan dayah sendiri tidak terlepas dari dukungan yang sangat kuat dari seluruh penduduk Aceh dan juga pemerintah, karena konsistensi pemerindath Aceh terhadap dayah maka dibentuklah badan-badan yang khusus menanganangani daya. Di antaranya, dibentuknya dinas pendidikan dayah.

\section{Perkembangan Dayah}

Masyarakat Aceh dewasa ini sangat sedikit mengetahui tentang keadaan pendidikan dayah di Aceh sebelum perang Aceh pada tahun 1873. Hal ini disebabkan karena perang Belanda di Aceh tersebut telah menghambat dan merusak sistem pendidikan Dayah di Aceh, dan sesudah Belanda berkuasa, merka membangun system pendidikan barat di Aceh. Sistem pendidikan barat di Aceh. Sistem pendidikan di Aceh pada masa itu meliputi pendidikan di meunasah-meunasah, rangkang, Dayah Teungku Chik, sampai pendidikan pada al-Jamiah seperti Mesjid Raya Baiturrahman Banda Aceh. Adanya lembaga-lembaga pendidikan seperti ini sebelum perang Aceh dapat dilihat pada berbagai situs peninggalan sejarah yang banyak sekali dari lembaga tersebut, di antaranya Dayah Teungku Awa Geutah di Peusangan, Dayah Teungku Chik di Tiro 
(Syekh Saman), Dayah Teungku Chik Taanoh Abee di Seulimum, Dayah Teungku di Lamnyong, Dayah Lambhuek dan Dayah di Krueng Kalee (Majid, 1997: 3)

Salah satu berita tentang Dayah adalah terdapat dalam Hikayat Pocut Muhammad. Selain itu sejarah mencatat bahwa ulama-ulama yang menjadi pemimpin Dayah, banyak yang datang dari luar negeri dan menetap di Aceh dalam berbagai lembaga penidikan Dayah, serta ulama Aceh sendiri merupakan ulama besar yang banyak pengalaman akademis, sehingga dapat dikatakan pendidikan Dayah di Aceh sebelum perang sangat metropolitan (Marzuki, 2011).

\section{Perubahan-perubahan dalam Pesantren di Aceh}

Sejak lama Dayah telah mulai mengalami perubahan-perubahan baik secara fisik maupun non fisik. Perubahan fisik yang jelas tampak antara lain:

a. Bentuk bangunan, yaitu telah mengadopsi gaya modern untuk bengunan-bangunan di lingkungan Dayah, disamping bangunan asli yang terdiri dari balai-balai. Selain itu sebagian dayah sudah mulai menyediakan ruang-ruang belajar dan papan tulis seperti di sekolah umum, begitu juga ruang perkantoran, koperasi dan aula serta asrama yang dulunya berbentuk kamar yang terkesan kumuh dan kotor, kini telah diganti dengan gedung asrama yang bernuansa modern.

b. Telah tersedianya fasilitas-fasilitas umum, seperti srana olahraga, perpustakaan, dan kantin, sarana seperti tidak dimiliki oleh Dayah-dayah di Aceh pada umumnya, karena sebagian menganggap olahraga hanya hura-hura dan tidak ada manfaatnya, begitu juga perpustakaan, santri memiliki kitab sendiri untuk belajar sesuai dengan kelas yang ia duduki. Disamping telah tumbuhnya kesadaran dan keterbukaan wawasan dari ulama atau para pemimpin Dayah, munculnya perpustakaan tidak terlepas dari peranan Badan Dayah Pemerintahan Aceh yang membantu menyediakan kitab-kitab dan buku-buku perpustakaan di Daerah (Marzuki, 2011).

c. Adanya pelajaran-pelajaran tambahan bagi santri, Diantara kegiatan ekstrakulikuler yang ada di Dayah saat ini adalah berbicara belajar bahasa Arab dan Inggris, belajar menulis, berceramah dan menjahit.

d. Penyelenggaraan sekolah tinggi agama Islam di lingkungan Dayah. Beberapa Dayah telah menyelenggarakan sekolah tingkat Tsanawiyah dan Aliyah dan bahkan banyak diantaranya telah mengadopsi model pesantren Ma'had Ulum ad-Diniyah Mesjid raya Samalanga (MUDI mesra).

Sekarang ini sudah banyak alumni Dayah yang menempuh pendidikan tingkat perguruan tinggi di IAIN dan STAIN/STAI. Para alumni kebanyakan bekerja sebagai guru, dosen, pengacara, penghulu dan penyuluh, pada tingkat mahasiswa para alumni Dayah telah membentuk organisasi alumni Dayah, IMADA (Ikatan Mahasiswa Alumni Dayah). Pada tingkat ulama dibentuk HUDA (Himpunan Ulama DAyah Aceh). Kedua organisasi ini memiliki peranan yang sangat penting bagi alumni Dayah (Marzuki, 2011)

Perubahan-perubahan yang terjadi di Dayah disebabkan oleh dua faktor utama, yaitu pertama, tuntutan masyarakat atau dunia kerja, sebagai negara sedang berkembang tentunya masyarakat Indonesia sedang mengalami perkembangan kea rah masyarakat modern. Karenanya, keberadaannya didukung oleh masyarakat, maka Dayah dituntut untuk menyesuaikan diri dengan perkembangan zaman, dengan tetap memperthankan cirri khas pendidikan Dayah sendiri. Para 
alumni Dayah diharapkan dapat berkiprah dan bersaing dalam dunia kerja serta ikut berpatisipasi dalam membangun masyarakat. Kedua, modernisasi dan globalisasi, arus modernisasi dan globalisasi sangat mempengaruhi para pemimpin Dayah dalam mengorganisasikan Dayah. Keterbukaan dan kebebasan informasi menjadikan para pemimpin Dayah lebih elastis dalam mengelola lembaga pendidikan Islam tersebut (Marzuki, 2011).

\section{Kebijakan Pendidikan Dayah}

Ada beberapa hal tentang kebijakan pendidikan dayah terutama setelah masa reformasi, pendidikan dayah menjadi "garapan" pemerintah, bergeser dari berbasis community based, kepada government based.

Pertama, tentang kebijakan klasifikasi dayah, bermula dari serangkaian keputusan gubernur masa Abdullah puteh 2003, kemudian diperbarui masa kepemimpinan Irwandi Yusuf tahun 2008, lalu diperbaiki lagi pada masa kepemimpinan Zaini Abdullah. Pemerintah mengklasifikasi dayah di Aceh secara komprehensif dan professional melalui tipikal dayah bertipe A, B, C dan non tipe. Fase inilah cikal bakal awal intervensi pendidikan dayah oleh pemerintah kita.

Kedua menyangkut dengan registrasi jumlah dayah, melalui keputusan Gubernur: 451.2/474/2003. Poin utama adalah registrasi dayah dilakukan setiap tiga tahun sekali, melalui dana APBD. Tahun 2008. Hal serupa dilakukan untuk penggunaan anggaran kepada pembangunan sarana dan prasarana dayah melalui Gubernur Irwandi Yususf yang dijalankan Badan Pembinaan Pendidikan Dayah (BPPD) dengan kewajiban melakukan koordinasi dengan dinas teknis terkait. Hal yang sama dilakukan oleh gubernur sekarang.

Ketiga Menyangkut kebijakan pemberian bantuan kepada dayah. Tahun 2003-2007, pemberian bantuan oleh Subdin Dayah Dinas Pendidikan Provinsi. Tahun 2008, menjadi wewenang BPPD berdasarkan Qanun 5/2007. Kemudian lahir Ingub 03/INSTR?2008 yang ditujukan kepada BPPD tentang petunjuk teknis pelaksanaan pembangunan dan pengembangan sarana dan prasarana dayah, menyebutkan bahwa pemberian bantuan dengan system kerjasama dan mengutamakan kepentingan santri dan masyarakat sekitar dayah. Jenis bantuan yang diberikan meliputi pembangunan mushalla, asrama, masjid, WC, dan bangunan utama pengajian. Di samping itu ada beberapa program jangka pendek yang dilakukan seperti pelatihan komputer untuk santri, pelatihan life skill santriwan (konveksi), pelatihan life skill santriwan (reparasi elektronik), bantuan ekstrakulikuler santri, musabaqah qirawatil kutub, sayembara baca kitab kuning, pelatihan jurnalistik, serta pembinaan dan pengembangan kurikulum dayah (Ilyas, 2016).

\section{Manajemen dan Pendidikan Dayah}

Pada penyelenggaraan pendidikan dayah, maka para perangkat (organisator) seperti teungku yang memiliki dayah harus mengikuti ketentuan atau prosedur dan tata cara pemerintah. Untuk itu, diperlukan kajian manajemen pendidikan dayah secara komprehensif. Mengenai manajemen pendidikan dayah di Aceh akan penulis jabarkan ke dalam beberapa poin berikut:

a. Kompetensi Pendidikan Dayah

Ada beberapa aspek kompetensi pendidikan dayah yaitu kompetensi dasar, menengah/lanjutan dan kepakaran. Kompetensi dasar adalah standar keilmuan dan keterampilan keagamaan yang wajib dimiliki oleh santri yang belajar di dayah dan memenuhi kebutuhannya 
untuk melaksanakan praktik agama dalam kehidupan sehari-hari. Kompetensi menengah yaitu standar pengetahuan dan dan keterampilan tangkat selanjutnya (tingkat lanjut) yang mencakup wawancara yang lebih luas dan pemahaman yang lebih mendasar dan mendalam terhadap ilmuilmu agama yang lebih beragam dan fungsinya dalam kehidupan di dunia dan akhirat. Santri yang menyelesaikan pendidkan menengahnya diharapkan tidak hanya mampu mempratekkan agama dalam kehidupan sehari-hari dikehidupan pribadi dan keluarganya, tetapi juga dalam kehidupan lingkungan (masyarakat) (Ilyas, 2016).

Kompetensi kepakaran adalah suatu standar bagi santri menguasai secara menyeluruh mengenai suatu bidang ilmu keagamaan, sepertiu fikih, usul fikih, ilmu falak, ilmu hadis, ulumul quran, tafsir, lughah, tarikh, tasawuf, dan sebagainya. Kompetensi ini diharapkan sebagai landasan bagi pencetakan kader-kader ulama yang pada akhirnya bisa memimpin masyarakat dan memutuskan persolan antara mereka dengan fatwa dan ijtihad yang sahih.

Lembaga pendidikan sangat membutuhkan sumber daya manusia (SDM) yang menadai dan memiliki kompetensi yang baik untuk mencapai tujuan pendidikan. SDM merupakan faktor penggerak terhadap sumber daya pendidikan, baik itu fasilitas,sarana dan prasarana, kurikulum, keuangan dan sumber daya lainnya sehingga dapat meningkatkan mutu pendidikan. Oleh krena itu, lembaga pendidikan perlu merumuskan manajemen dan perencanaan SDM secara terintegrasi, strategis, saling berkaitan dan menyeluruh sehingga dapat mencapai tujuan pendidikan secara efektifdan efisien (Hasnadi, 2019).

Peningkatan mutu pendidikan dayah mencakup: pertama, kebijakan pendidikan. Kebijakan klasifikasi dayah dan registrasi dayah harus bersifat update Program jangka pendek yang dilakukan Pemda Aceh, seperti pelatihan komputer untuk santri dayah, life skill santriwati (konveksi), life skill santriwan (reparasi elektronik), bantuan kegiatan ektrakulikuler, musabaqah qiraatul kutub, sayambera baca kitab kuning, pelatihan jurnalistik, pembinaan dan pengembangan kurikulum dayah haarus holistik (Ilyas, 2016).

b. Biaya Pendidikan

Mengenai biaya pendidikan dalam Qanun pendidikan pasal 17 ayat (2) point a disebutkan bahwa kewenagan pemerintah kabupaten/kota dalam bidang pembiayaan pendidikan meliputi penyediaan bantuan biaya penyelenggaraaan pendidikan formal, nonformal dan pendidikan dayah sesuai kewenangannya, pada point $b$ disebutkan pembiayaaan penjaminan mutu satuan pendidikan sesuai kewenangannya. Dalam pasal 46 ayat 3 isebutkan pengelola dana pendidikan pada saluran pendidik dayah yang berasal dari semua sumber penerimaan ditetapkan dalam perencanaan anggara pendapatan dan pembelanjaan dayah (RAPB) atas hasil kesepakatan musyawarah pimpinan dan teungku dayah dengan disetujui oleh intansi Pembina di kabupaten /kota (Ilyas, 2016).

c. Kurikulum dan Sarana Prasarana Pendidikan

Dalam Qanun nomor 5 tahun 2008 pasal 35 ayat (6) dan (7) disebutkan bahwa kurikulum dayah salafiyah ditetapkan oleh pimpinan dayah yang bersangkutan berdasarkan hasil musyawarah pimpinan Dayah. Dayah terpadu/modern yang menyelenggarakan program sekolah/madrasah mengikuti kurikulum sekolah madrasah. Mengenai sarana dan prasarana pendidikan juga dibahas secara terpisah dalam Qanun yang sama pada pasal 19. 
d. Peningkatan mutu pendidik dan tenaga kependidikan

Peningkatan mutu dapat dilakukan dengan melakukan pelatihan bagi pimpinan dan guru dayah, melakukan supervisi secara berkelanjutan (Herman, dkk, 2020) dan melakukan evaluasi.

e. Pengendalian terhadap mutu pendidikan.

Dayah memerlukan perhatian yang serius dalam beberapa hal, diantaranya bidang manajemen, pendaan dan kurikulum. Dalam pendidikan mutu daya, aspek peningkatan mutu harus diperbaiki yaitu SDM mencakup pimpinan dayah, tenaga pengajar, pimpinan dayah di Aceh disebut $a b u$, abah, abi dan walid. Semua kata-kata tersebut berasal dari bahasa Aceh yang bermakna "ayah" (Ilyas, 2016).

\section{Keberadaan Dayah di Aceh Tenggara}

Mengingat Aceh Tenggara merupakan salah satu daerah yang berbatasan langsung dengan Sumatera Utara, keberadaan dayah di daerah tersebut sangat penting sebagai upaya mendukung pelaksanaan syariat Islam di Aceh dan juga untuk menjaga akidah anak-anak yang tinggal di wilayah tersebut. Dayah harus bisa menjadi basis pendidikan agama Islam di pintu masuk Aceh.

Menurut Kepala Kantor Kementrian Agama Aceh Tenggara, M. Idris yang dihimpun salah satu surat kabar yakni Serambi Indonesia pada tanggal 15/12/2017. Menyatakan bahwa selama ini kriminalitas dan maksiat di Aceh tenggara marak terjadi Di Aceh Tenggara, salah satu cara menanggulanginya adalah dengan mendirikan atau memperbanyak pondok pesantren. Beliau menambahkan "Setiap desa yang mayoritas muslim harus mempunyai minimal satu pondok pesantren tingkat SD, SMP, dan SMA. Sebab dengan kehadiran Ponpes di Desa-desa, dapat mengantisipasi kriminalitas dan maksiat. Berdasarkan pernyataan di atas dapat disimpulkan dukungan segenap elemen masyarakat dan pemerintah sangat menaruh perhatian khusus terhadap kehadiran dayah di Aceh Tenggara.

Menurut data dari UPTD dayah Aceh Tenggara, jumlah pesantren/dayah di Aceh Tenggara berjumlah 38 buah dayah. Masing-masing dayah tersebut digolongkan kedalam beberapa tipe, yakni tipe A, B, dan C. juga terdapat dayah non tipe dan juga ada sebagiannya yang belum termasuk dalam ketiga tipe tersebut.

Dayah-dayah yang tergolong ke dalam tipe A, yakni berjumlah 9 dayah. Kemudian dayah yang tergolong dayah tipe B berjumlah 6 dayah, dayah yang tergolong tipe $\mathrm{C}$ berjumlah 8 dayah. Dan 7 dayah yang belum tergolong dalam tipe (non tipe). Terakhir ada 8 dayah yang belum dimasukkan kedalam tipe-tipe tersebut.

\section{Pembentukan Karakter Pemuda melalui Proses Pendidikan Dayah}

Dari hasil penelitian dilapangan dengan melakukan observasi dan wawancara terhadap Dayah-dayah kemudian terhadap Pimpinan, dewa guru dan santri yang ada di pesantren tersebut Mengindisikasikan bahwa pendidikan Dayah memiliki peran yang penting dalam pembentukan karakter pemuda. Bahkan pendirian suatu dayah di mulai dari inisiatif masyarakat sendiri dengan cara gotong royong. Minat para pelajar untuk belajar di Pesantren/dayahpun sangat tinggi ini bisa dilihat dari setiap tahunnya para pelamar terus naik. Sekarang juga di Aceh Tenggara dapat dikatakan sebagai salah satu kabupaten yang memiliki dayah terbanyak. Terutama untuk mengubah karakter santri. Berdasarkan hasil wawancara yang penulis lakukan terhadap 
pimpinan dayah dan para dewan guru secara umum dapat ditarik benang merah yaitu keberadaan dayah sangat dibutuhkan kehadirannya serta eksistensinya ditengah-tengah masyarakat di Kabupaten Aceh Tenggara.

Dukungan akan kehadiran dayah juga lahir dari masyarakat hal ini dapat dilihat dari minat para calon santri yang mendaftar ke dalam pesantren tersebut meningkat dari tahun ke tahun. Lulusan dari dayah-dayah tersebut juga langsung bisa dirasakan oleh masyarakat. Di antara lulusannya bisa menjadi pendakwah, imam, khatib dan sebagainya. Cerminan akhlak dari para lulusan dayah juga sangat dikagumi oleh masyarakat. Dari sudut pandang santri setelah penulis melakukan wawancara, santri-santri tersebut merasa selama menuntut ilmu dan tinggal disana telah membentuk karakter baik dari segi tingkah laku, sikap dan sopan santun yang mereka rasakan selama menuntut ilmu di dayah. Mereka juga merasakan apa yang mereka dapatkan selama belajar di dayah dapat bermanfaat pada orang tua dan masyarakat.

Pembentukan karakter dapat dilakukan dengan cara menciptakan kondisi yang mendukung penanaman nilai-nilai karakter, keteladanan, kegiatan spontanitas, kegiatan terpogram, kegiatan bimbingan konseling dan kegiatan ekstrakurikuler, kegiatan 5S (Salam, Senyum, Sapa, Sopan dan Santun); budaya tadarus; budaya membaca doa ketika memulai dan mengakhiri belajar; budaya disiplin; dan budaya bersih; budaya jujur; dan budaya malu ketika berbohong dan datang terlambat, tidak berperan aktif dalam menjaga kebersihan lingkungan dan melanggar peraturan serta kegiatan peringatan hari besar Islam (Hasnadi, 2018).

Hambatan-hambatan yang dihadapi tidak terlalu signifikan karena dukungan pemerintah terhaadap dayah di Aceh Tenggara sangat intens. Hambatan mungkin yang timbul lebih kepada bagimana mendidik seorang santri yang baru masuk di Dayah kemudian mendisiplinkan mereka dari berbagai kebiasaan keseharian mereka.

\section{KESIMPULAN}

Dayah merupakan salah satu lembaga penddidikan yang sudah sejak zaman kemerdekaan bahkan sebelumnya. Dayah salah satu tempat menuntut ilmu-ilmu agama. Di hati masyarakat Aceh Dayah salah satu lembaga pendidikan yang mengangkat marwah bangsa Aceh dan banyak mencetak-cetak ulama yang terkenal hingga ke mancanegara. Dayah dari masa ke masa telah mengalami perkembangan hal ini mengingat kondisi zaman yang semakin berkembang. Sekarang di kenal ada Dayah modern dan ada yang tradisional. Dayah modern mengadopsi dua jenis pendidikan yakni pendidikan tradisional dan modern, sementara Dayah yang tetap mempertahan tradisinalitasnya yakni khusus mempelajari ilmu-ilmu agama. Sekarang Dayah modern ini yang banyak dijumpai di sebagian besar wilayah Aceh. Namun demikian, ada juga beberapa dayah di Aceh yang tetap mempertahankan ketradisionalitasnya. Walaupun ada perbedaan namun, secara umum kehadiran Dayah adalah identitas masyrakat Aceh yang dikenal dengan keilmuan agama masyarakatnya yang kuat. Sehingga Aceh diberi julukan Serambi Mekkah dan diberi juga kekhususan untuk menjalankan syari'at Islam. Perannya dalam pembentukan karakter pemuda di Aceh Tenggara juga sangat signifikan. Hal ini dapat dibuktikan dengan keadaan masyarakaat di Aceh Tenggara yang sangat menginginkan keberadaan dayah terus eksis di Daerah tersebut. 


\section{DAFTAR PUSTAKA}

Hasnadi, H. (2018, December). Penerapan Pendidikan Karakter Berbasis Budaya Sekolah di SD Negeri 15 Kota Banda Aceh. In Seminar Nasional Bimbingan Konseling 2018.

Hasnadi, H. (2019). Perencanaan Sumber Daya Manusia Pendidikan. Bidayah: Studi Ilmu-Ilmu Keislaman, 10(2), 141-148.

Herman, Jamaluddin Idris, Nur Asiah, Nur Anifah, Hasnadi. (2020). An Amanah Approach of Supervision Model to Improve the Performance of Islamic Education Teachers at Public Junior High Schools in Nagan Raya. International Journal of Advanced Science and Technology, 29(08), $201-210$.

Ilyas, M. (2016). Pendidikan Dayah setelah Undang-Undang Pemerintahan Aceh. Kanun: Jurnal Ilmu Hukum, 18(3), 469-484

Majid, Nurchalis. (1997). Bilik-Bilik Pesantren: Sebuah Potert Perjalanan, Jakarta: Paramadina.

Marzuki, M. (2011). Sejarah Dan Perubahan Pesantren Di Aceh. Millah: Jurnal Studi Agama, 11(1), 221-233.

Mashuri, M. (2013). Dinamika Sistem Pendidikan Islam di Dayah. Jurnal Ilmiah Didaktika: Media Ilmiah Pendidikan dan Pengajaran, 13(2).

Moleong, lexy J. (2007). Metodologi Penelitian Kualitatif. Bandung: Remaja Rosdakarya.

Muhammad AR. (2010). Akulturasi Nilai-Nilau Persaudaraan Islam Model Dayah Aceh, Jakarta: Badan Litbang dan Diklat Puslitbang Lektur keagamaan, Kemenag RI.

Sugiyono. (2007). Metode Penelitian Kuantitatif Kualitatif dan $R \&$ D. Bandung: Alfabeta.

Sukmadinata, Nana Syaodih. (2009). Metode Penelitian Pendidikan. Bandung: Rosdakarya. 